\title{
ERRATIC BEHAVIOUR OF THE UNITED NATIONS AND GLOBAL GOVERNANCE IN AFRICA: THE STATE AS A SMOKESCREEN FOR WORLD SECURITY
}

\author{
Agbo Uchechukwu Johnson ${ }^{1}$ \\ Nsemba Edward Lenshie ${ }^{2}$ \\ Ndukwe Onyinyechi Kelechi ${ }^{3}$
}

\section{Introduction}

State's choice for human beings emerged when they realized that wild freedom in the "state of nature" where power is right, failed to achieve life and property independence and protection. Human beings were forced to capitulate for the common good to the abstract government. In what Hobbes (I588-1678) called the "social contract", the state acknowledged this obligation to be governed by a leader of an all-powerful society. In his Second Treatise of Government (i689), John Locke (I632-I704) also agreed with Hobbes' notion of a social contract, based on the premise that human beings are born free. Individuals enjoy a natural right to life, freedom and the freedom to own or possess estates.

The state is to facilitate the social contract and free humanity from the fear and danger of violent death to pursue every aspect of civilization. It was in appreciation of the state's all-important domestic position that it was aligned with global governance (Gordenker and Weiss I995). This contrib-

I Federal University Wukari. Wukari, Nigeria. E-mail: agbojohnson@gmail.com

2 Department of Political Science and International Relations, Taraba State University. Jalingo, Nigeria. E-mail: edward.lenshie@tsuniversity.edu.ng

3 Department of Political Science, University of Maiduguri. Maiduguri, Nigeria. E-mail: onyinyechi.kelechi@yahoo.com 
uted to the establishment of supranational bodies, and after World War II in I945, the UN. The UN acknowledges the state as the centre of its success in preventing violent deaths, wars and protecting humanity from burdens which may impede its independence. It was on these grounds that the UN Intellectual History Project (2009) divided the supranational body into three, naming the UN member states as the "First", the UN Secretariat as the "Second," and the non-state actors (Non-Governmental Organizations (NGOs), scholars, consultants, experts, independent commissioners) as the "Third" UN (Weiss and Gordenker I996; Weiss, Carayannis and Jolly 2009).

Another important feature of the UN and the state is that, in effect, the UN Charter was founded on the concept of state sovereignty as a protective concept of equality among states - the principle that could only strengthen the protection of the power of the smallest and weakest states (Gordenker and Weibb I995, 4I). We may agree with the classifications and concept of sovereignty in favour of the state as the "First" UN, but in our view, as the "Third" UN, we may have neglected the states that emerged stronger in the post-World War II with certain forces measures in the UNSC.

While it can be believed that there is constitutional equality among both the "strongest and weakest states" in the UN system, the "strongest states" relationship with the "weakest states" has been strikingly unequal. This situation then makes it imperative to study in the context of the UN the "strongest states", also called the "super-states" in their engagements with the weaker states. Perhaps more interesting is that international bodies, including the UN, the North Atlantic Treaty Organization (NATO), etc., are used by the "super-states" 4 as tools to promote their interests. The UN has provided the framework in some cases, but more frequently the UN has been side-stepped or side-lined by new membership organizations controlled by rich countries or other independent organizations. The foregoing poses awkward concerns

4 The context in which the "super-states" term is used explicitly refers to the "great powers" or strong countries. These primarily include the US, the United Kingdom, France, China and Russia who are members of UNSC. However, it also includes other potent countries such as India, Japan, and Germany. They are treated differently from other wider UN membership because of their large contributions to the UN each year. Though independent in its own right, the UN depends on its "generosity" to fulfil its functions. 
regarding UN "global governance" 5 structures and control, democratic transparency and universality - and perceived importance, competency, and the UN's political weight (Overseas Development Institute I999, 2).

This paper interrogates, as a corollary, the manifestations of the UN's erratic conduct in the sovereignty given to states, with emphasis exemplified in the crises of Côte d'Ivoire and Libya. In this study, the first part is preceded by the introduction that provided the background to the erratic behaviour of the UN in the context of global governance in relations with states. The second part examines the state and the UN to understand the policies and manoeuvres within the supranational organization. Part three focuses on colonialism and the consequences of state formations for Africans. The question of states' autonomy inside the UN is brought to the front burner in part four. Part five answers the question of who governs the African states, while the specific cases of Côte d'Ivoire and Libya are discussed in part six and seven. The final part, which is the eight, ends with a few constructive suggestions.

\section{The UN and the state: Understanding the complex dynamics}

Policies within the UN system can be put clearly in the sense of the central role that modern states play in global governance (Gordenker and Weiss I995). Six or seven hundred years ago, though, people did not think of themselves as belonging to a nation or state as we know it today. Most people were living on subsistence farms, deeply worried with the village where they do not think much for the world outside. Armies raided these villages at times, but for the villagers, whether the army was employed or not, it did not make a major difference. For them, the army as a state did not matter; it was contextualized only within the realm of the "state of nature" (Shivery 2008, 4I).

5 Global governance, also known as "global governance", is a philosophical framework that represents the establishment of "the absence of overriding political power, such as in the international system, is regulations of interdependent ties" (UN 2OI4, 3). Loosely defined global governance aims to provide global public goods, particularly peace and security, justice and conflict resolution systems, functional markets, and unified trade and industry standards (Global Change Foundation, https:/globalchallenges.org/global-governance). Replaced by a global governance system focused on communities of selected countries, the existing UN Global Governance Framework endangers Resolution 65/94, which accepts inclusive multilateralism (Gálvez 20I4). 
Thereafter, state formations emerged in the form of dynastic empires, kingdoms, emirates, and city-states. They emerged from the emergence of a modern state that has continued to abound and collapsed. 1648 , the date of the Treaty of Westphalia and the time when the State structure started to take its current form is assigned. It is therefore important to submit that the establishment of states had occurred before Westphalia (Empires, Kingdoms, Emirates and City-States) and had relations with each other, but they did it on a very different basis (Palmer and Perkins 2004, 5). The modern states are related to the peace treaties of Westphalia of 1648 , which entered into force after about thirty years of war (Cassese i986).

A state is a political unit which essentially has jurisdiction, that is, a political unit which has absolute responsibility for conducting its affairs. France is a state, the US is also a state, and Brazil, Libya, and Côte d'Ivoire are also states founded on the principle of "sovereignty" (Shively 2008). Therefore, in the international sense, a state is a group of people established within a territory recognized as their own; they have a government, and most importantly, they are sovereign. This means the people are free from some sort of foreign control, such as colonialism, but may not be free from neo-colonialism. ${ }^{6}$

Modern features of state typically include land, people, government, and sovereignty. Although international regulations under the UN Charter acknowledge these qualities of states, state actors jealously guard the "sovereignty" of their country, but they are now linked together in a "myriad of

\footnotetext{
6 In Africa colonialism predated neo-colonialism (Sartre, 200I). Colonialism is one country's direct and overall domination by another based on a foreign power in the hands of state power (Ocheni and Nwankwo 20I2, 46). In Africa, the industrial revolution in Europe strengthened colonialism, which necessitated the need to hunt for raw materials and markets for the industries' surpluses (Chamberlain 2013). The Berlin Conference of I884-1885 led to the scrambling and partitioning of Africa and supplanted the pre-colonial formations of the African State and reinforced post-colonial neo-colonialism (Sartre 200I). Segell (20I9, I84) described neo-colonialism as "the regressive effect of uncontrolled forms of aid, trade and foreign direct investment; and African leaders cooperate with foreign leaders to ensure that the interests of both are met with little regard for African countries' growth, prosperity, and poverty reduction and well-being."
} 
resolutions" that prohibit them from the use of force to resolve disputes, but by peaceful means and legal criteria, and compel them to comply with certain requirements (Cassese I99I, 256).

The UN is a not a world government (UN 2000), but an association of I93 states (including South Sudan), nearly half of the world's nations, and takes responsibility for many of the activities that a government within a state should do. That is, they are concerned with upholding law and order by avoiding violent conflicts. Although the UN is trying to do the stuff a country is doing, it cannot do them the way a country does. It does not have its army or police to execute its decisions. Instead, it must depend on the voluntary assistance of its member states (Shively 2008, 405). We may assume that the repeated decimal of states' sovereignty is a measure of equality in the UN, but there are substantial disparities between states in terms of population, wealth, culture, environment, government, military strength, and every other significant respect (Palmer and Perkins 2004, 2). Yet Article 2 of the Charter of the UN is based on "the principle of the sovereign equality of all member states." The incoherent concept of UN equality of states challenges the "Third" UN.

The UN was created as a regime by the victorious allies after World War II to help sustain world peace. This was to be achieved partly by enforcing sanctions on the broker of peace and partly by people-based programmes to eliminate factors causing conflicts (deprivation, misery and ignorance, etc.) (Shively 2008). Like the states were meant to serve the interests of merchants and industrialists who created them, also was the UN created by the super-states. In the UN, the super-states are leaders of military alliances and controllers of competing international production and trade systems. This defines their political values, in this context capitalism which they export to every part of the world, especially Africa.

The aggressive process of state creation in Africa by the colonialists was to serve capitalists interests. The African states have to find their feet in a deeply unequal world of distribution of global power and resources which put

7 The "myriad of resolutions" refers to the numerous UN resolutions meant to guarantee security and safety of the sovereign State from both internal and external threats and affronts to its existence and people. These resolutions include "responsibility to protect" articulated in paragraphs I38 and I39 of the World Summit Outcome Document; "human security" enshrined in the UN General Assembly resolution 66/290, and "protection of civilians in armed conflict" which the peacekeepers are authorized to make use of all means, including the use of deadly force to prevent or respond to threats of physical violence against civilians, within capabilities and areas of operations, and without prejudice to the responsibility of the host government (United Nations 20I0; 20I5). 
Africa at the bottom of the heap without any empirical qualities of statehood necessary to sustain sovereignty internationally (Clapham I995). In Africa, over one hundred of today's I93 states were colonies of European nations. In other words, there are more than twice as many states in the world today than there were in I94I. Together these emerging states and some older states make up the global south (Africa, Asia and Latin America). These states in the global south have dramatically changed the international landscape because they dominate much of the natural resources of the world and contains about three-fourths of its population. However, they do not possess a proportionate share of resources or military strength; they are weak individually (Shively 2008: 397), correlating with the fact that they were created by the super-states through collective imperialism.

Collective imperialism is rooted in liberalism, on the common philosophy of the nation is its guiding principles, not state sovereignty. It is this collective imperialism that they call globalization. A group of neo-Marxist writers, such as Paul Sweezy, Harry Magdoff, André Gunder Frank and Samir Amin in the I970s, theoretically clarified the idea of collective imperialism. In the several writings of André Gunder Frank and Samir Amin, the theoretical framing of collective imperialism continued to resonate to prominence. The discourse on collective imperialism is related to the role of the triad's nation-states (the US, members of the European Union, Japan) in the world's unequal relations between the metropolis and the periphery. Samir Amin (20I5) argues that the collective imperialism in the triad nations is rooted in the consciousness of the bourgeoisie to jointly manage the world, especially the peripheral countries. In its globalized deployment, Andre Gunder Frank (I978) situated collective imperialism in the capitalist accumulation in the metropolis through unequal exchanges with the countries in Asia, Africa and Latin America, thus creating dependency and underdevelopment in those continents.

Globalization is the shrinking of states' national boundaries to allow for interconnection, integration and interdependence. Globalization is, according to Samir Amin $(2003,6)$, the global expansion of capitalism, the structural transformation of the system of an accumulation from one period of its existence into another, and, in effect, the successive types of asymmetric centres/peripheries fragmentation of concrete imperialism. Globalization generates a "global value" for the creation of capital on an economic scale by polarizing the world. This is accomplished by building dominant centres and dominated peripheries, and continuous character reproducing and deepening the polarized domains (Amin 2003, 5-6). Power over capital is concentrated in the metropolis which drives capitalism and capitalist development globally 
as it does in ties with their partners. This character has dramatically changed the nature of states as major players or actors in the international system. Despite the role played by globalization reinforced by collective imperialism, national supremacy, national decision-making and territorial borders have not vanished and the states remain the major players in international affairs. In contemporary time, states, however, have become ever more accessible and vulnerable to external pressures (Speros and Hurt 2003, 390).

The globalization of capitalism that penetrates the peripheries with the centralization of capital in the metropolis has not led to the establishment of a world government, but mails are sent across the boundaries of various countries in different continents on any given day; people fly from one country to another; goods and services are transacted across the land, air, sea and the cyberspace. In the fair assumption of protection and security for the individuals, organisations, businesses, and governments involved in the process, a whole range of other cross-border activities occur. In this context, collective imperialism has become domesticated as much as the control of capital by the triad nations is about the production sector of capitalism segmented and located in different parts of the world (Amin 2015).

Collective imperialism produces structural disturbances and challenges that are more, and in many cases, less frequent in the international domain than in many sovereign countries which should have a successful and functional government (UN Intellectual History Project 2009, I). What this means is that the UN secures the external space from disputes than the states within the international system. In the international system, the African states are most hit by internal disputes considering their colonial history which arrested the development of indigenous state formations. Colonialism and postcolonial states in Africa have maintained the anti-human processes of imperialism, given the clauses in the UN Charter which is aimed at maintaining peace through "human security" ${ }^{2}$ approach.

8 "Human Security" in the context of UN General Assembly Resolution 66/290, "is a strategy to help member states recognise and resolve common and cross-cutting threats to their people's security, wellbeing and dignity." Human Security calls for "people-centred, systematic, context-specific and prevention-oriented approaches that strengthen protection and empower their people." 


\section{Colonialism and the consequence of African state formations for Africans}

State formations in Africa were at the pinnacle. As the industrial revolution in Europe forced their merchants to find raw materials outside Europe, Africa became the contact point. Having had a long history of the slave trade in Africa, it was replaced with imperialism and colonialism. While African empires, kingdoms, emirates and city-states resisted European invasion, superior military power was used to subjugate them, enhanced at the "Berlin Conference."9 For Young (I99I, 24), Africa's colonial occupation was comparatively dense and thorough. The multiple infrastructures of domination were established to ensure the successful occupation of African communities as a condition for security, property rights, the exploitation of raw materials and labour-service, and the fiscal tribute to self-financing of alien hegemony.

At the Berlin Conference, the problems of African states started when the architects of the division made them foreign entities without local contents intended to represent the interests of the centre/metropolis. Johnson (I975, I08) noted European nations benefited by exploiting and expropriating capital from the forced labour of the indigenous people in Africa. The modern states in Africa have remained foreign bodies to Africans. Africans had the imposition of statehood regimes that were not in line with the existing political structures that predated colonialism and the advent of modern states. In the process of colonization, there was no point in representing the needs of Africans in the process of colonialism and building of colonial empires in Africa (Shively 2008, 395). In Africa, the relationship between nation and state is especially lost due to externally mediated state formation. Many African states' boundaries are leftover from the colonial era when they were drawn to suit the convenience of the colonizing powers.

While the imposition of the static colonial boundaries would appear as a remarkable improvement for the continent and its inhabitants, in Africa it is a disruption to the development of indigenous states. The European continent went through thirty years of war which resulted in the Westphalia treaty that led to the states in Europe. The lack of participation from Africans

9 The Berlin Conference brought together in Berlin between I5 November I884 and 26 February I885 scramblers (Belgium, Germany, Great Britain, France, and Portugal) of African territories to the official residence of German Chancellor Otto von Bismarck on Wilhelmstrasse (Gathara 2019). Otto von Bismarck participated and mediated in the African continent's cut-throat competition, which led to the formalization and mapping of Africa for European scramblers staking interests to gain territories in Africa. By the I990s, European scramblers have colonized 90 percent of African territory (Heath 20I0). 
in the course of their state creation, as in the case of Europe's Westphalia treaty, made the people of Africa disown the state because it is a foreign implant. African states have not been indigenised to date; they follow the institutional frameworks put in place by the European powers, cursorily with brazen disregard to the socio-economic and political development in Africa.

Although European institutions are designed to work for the people, colonialism transformed the institutions in Africa into working against the people. Thus, after independence in the I950s and I960s, African governments inherited colonial statehood trappings and continued them. The Armed Forces formed to serve a larger, imperial scheme; the Police Forces organized to hold the natives in check and to keep any resistance against the government at bay as well as the colonial laws established to protect the imperial powers were transformed after independence to protect the rulers of African states mainly chosen by departing imperial powers. These combined forces fortified the state against the citizens in Africa. African states were controlled but not governed, and contemporarily, still reflects the dominant character of the colonial state structures, which explains the rapture of the state from the society in Africa.

\section{The UN, the super-states and the questionability of the sovereignty of African states}

The statehood of states colonialists handed down to African rulers at independence has been questioned. The questionability of statehood in Africa contributes to the debates on the enormity of problems faced by African states. African states are recognized as autonomous and sovereign, and as such have seats at the UN. However, does that make any sense? And, do they have equal votes and opinions in the UN? In this context, the concept of sovereign equality is challenged. It is more fitting to describe African states as "quasi-states." Quasi-states are recognized by other states within the international framework as sovereign and autonomous entities, but are unable to meet the demands of substantive statehood, which includes the capacity to exercise effective control within, and able to protect territorial boundaries against external attacks (Jackson I990).

It can best be illustrated by the role that France and Great Britain play in Africa on behalf of the common interests of the imperialist centre. Unlike the role played by Great Britain, France formally played a dominant role in ruling about seventy sub-Saharan African states. France's relationship with 
the bloc African de premier has made the staff politically, culturally, economically and militarily to be tutelary, sometimes intrusive, and often blatantly interventionist (Young I99I, 27). France has built an unprecedented relationship with Francophone African governing leaders, beyond those needed by its cold war ambitions and expressed in an average of one French military intervention in Africa per year from ig60 to I994.

France's alliance with the Francophone African states strengthens its position as a post-colonial world power. That is evident also in many former colonialists' relationships with their former colonies in Africa. France and other Western "super-state" continue to enjoy their roles as world powers in the Western bloc, as does the Eastern "super-state", although African governing elites continue to gain as reliable allies. These super-states continue to provide them with the economic, political, technical and military help to entrench dictatorial rule in Africa (Chafer 2002, 344). The argument is that French and British relinquished their colonial domination in Africa, albeit not by default but as a result of post-World War II activities in which the US and the UN were active actors. It also followed that in neo-colonialism; they saw an opportunity that benefited the US and others - Western and Central European countries and Japan, that turned the multiplicity of imperialism of the pre-World War II into collective imperialism.

The US, which emerged stronger in the capitalist world, was accommodated in the collective imperialism and became the hegemonic leader in that respect. Samir Amin (2004) notes that this modern mode of colonial expansion has undergone various stages of development yet remain present. This viewpoint must be placed in the ultimate hegemonic position of the US that it articulates within the current global imperialism. France and Great Britain act and manoeuvre their former colonies to serve their purpose. However, in most African countries, the ruling class were prepared to take power to serve the purposes of their former colonialists in post-independence Africa.

Under the rules of capitalism, the conservative capitalist class in control of state power opposed functioning. African leaders are forced to give up authority or deposed, either peacefully or violently, because of their resistance. In most cases, the method of the new regime is to hide under the UN resolutions, while its stooges are permitted to transform the state into patrimonial governance. While France, Great Britain, the US, and other Western powers have continued to be major players in the African states, new strategic dynamics and the scramble for the continents have emerged along with the divisions between the Western and Eastern super-states. As the US has recently reduced participation in Africa, the Eastern super-states, 
particularly China and Russia have, among others, increased their presence in Africa to control and protect their political and economic interests. China and Russia in Africa have shown remarkable interest and involvement. In October 2000, China hosted 44 African countries for their first Chinese-African Cooperation (FOCAC) in Beijing, named the Sino-African Social and Economic Development Partnership. Since then, China has strengthened its socio-economic partnerships among others in the resource-rich countries of Angola, Algeria, the Democratic Republic of Congo and Nigeria (Yachyshen 2020).

In a related context, Russia held the first Russia-Africa summit in Sochi, in 20I9. The summit concentrated on developing trade ties, securing energy projects, and military agreement with African countries. Its involvement in Africa revolves around the need to extend its power and influence, exploit conflicts, manipulate governments and sell weapons across Africa. Russia's activities are predatory and contradict US interests as its effort is to subvert democracy and create continental authoritarian regimes. Central African Republic (CAR), Libya, Madagascar, Mozambique, and Sudan are countries with which Russia interacted and transacted trade relations. Since 200I Russia has sold weapons, fighter jets, combat helicopters, and military equipment to the Bashir government in Sudan (Yachyshen 2020).

China and Russia's presence in Africa purchasing large-scale assets, signing deals, and collaborating to exploit reserves of natural resources, negotiating and manipulating governments across the continent has led to an escalation of friction with the US. China's aid, loans, foreign direct investment and alliances to African rulers in an attempt to develop their foothold on the continent has raised the question of whether Africa is being recolonized. China's imperialism and out-drive of Russia in Africa more subtly and actively strengthens collective imperialism used to subvert the autonomy and development of African states in contemporary times.

\section{The UN, the super-states and the violation of the sovereignty of African states}

Throughout the debate on political science, governance has become a key topic. To achieve mutual goals, the concept is correlated with the concept of government used to exercise control of individuals and groups in socio-economic and political relationships. The state has a major role to play in controlling institutions that will strengthen governance for mutual benefits 
in the state. The UN as a sovereign nations' body, it is an individual state voluntary organization and not a world government. Though the UN General Assembly has the right to address all matters within the framework of the Charter and make recommendations. However, it has no power to force any state to act. Yet, its proposals bear the moral weight of world opinion (UN 2000). To achieve its purpose, the UN relies on the super-states to fill the void of power to order obedience among member states.

The UNSC on 25 January I946, set up the Military Staff Committee by the provisions of Article 43, paragraph I of the Charter of the UN military arm to give it teeth, which specified that "all members of the UN to contribute to the maintenance of international peace and security, undertake to make available to the Security Council, on its call and by a special agreement, armed forces, assistance, and facilities, including the rights of passage, necessary for maintaining international peace and security." This clause violates the sovereignty of the weaker states, or that the super-states which authored the UN usurped the supremacy of the weaker states (Murthy 20I8; Boulden 2013; Goulding I999). It also describes the predicaments in the international framework for African countries. The dynamics of the Cold War-era further aggravated the problems for African states. Today, the super-states in the UNSC uses the UN to establish global hegemony and weaken the values of the supranational organization.

In retrospect, under the UN watch, the super-states behaved contrarily in Africa. Few of the erratic behaviour of the UN acted through the super-states are thus chronicled:

- In Congo Kinshasa, after independence in I961, the super-states backed Prime Minister Patrice Lumumba's kidnapped and tortured to death by his political opponents, Kasavubu and Mobutu, from the legitimate secured and guaranteed custody of UN arms forces. In the Congo crisis, UN Secretary-General Dag Hammarskjöld's death in an aircraft crash was not unconnected to the shreds of facts associated with the death of late Patrice Lumumba.

- The UN referred to the I963-68 Mau-Mau freedom rebels in Kenya were labelled an African extremist group to be defeated on British Kenya's territory. The UN refused to counter the Kenya Mau-Mau fighters' assault and massacre but supported British colonial settler troops.

- The UN and all the European and Western powers declined to officially condemn the Portuguese, the South African apartheid 
regime and France's military intervention in the civil war in Angola (I968-72). In the civil war, the Western powers backed Mr Jonas Savimbi to the teeth to overthrow Angola's constitutional government.

- The disastrous plane crash in the sense of a regime change leading to the death of Mozambique President Comrade Samora Machel in I986, which the UN rejected for certain considerations, calling it an unfortunate air crash and technical navigation and weather mistake.

- The South African apartheid regime was colonial, authoritarian, and repressive and, above all, violated the political and human rights of the indigenous South Africans, yet it was accepted and acknowledged as a member of the UN.

- In the Republic of Rwanda, the first true African genocide happened between 1994 and 2000 . The ironic UN blue helmet was fully-armed peacekeepers in the territory of Rwanda but failed to prevent the I994 assassination of Juvenal Habyarimana, the first constitutionally elected President of Rwanda. This prompted the ethnic revengeful killing of the Tutsi people by an instant Hutu people, whom they suspected of murdering President Habyarimana. In this background, Shively (2008) accused the West of a half-hearted response to the Rwandan genocide, manipulated by France to continue supplying arms to the Hutu militias carrying out the coordinated murders and defence of the Hutu government as it fled the victorious rebels; The US government and its diplomats were also accused of failing to name it genocide against Tutsi and delayed the arrival of logistical support to African troops to help restore order to Rwanda.

- The present Republic of Somalia, the political, humanitarian, economic and social crisis has arisen from I991 to 2012. Where was the UN? Why has the UN recently acted when the entire Somali population has been almost witnessing extinction from the face of the Earth?

- The I964 Zimbabwe, under the British white farmers-settlers and the then Prime Minister Ian Smith's political system, was wholeheartedly supported by the UN against the political aspiration of the black majority of Zimbabweans. The Black Zimbabwean war of liberation from the shackle of white Zimbabwean farmer settlers and the Apartheid racist South Africa only suc- 
ceeded in I987, with the arrival of the then anti-colonialist, ZANA / PF nationalist Black Zimbabwean President Robert Mugabe. The UN, which fully supported Prime Minister Ian Smith's white minority government from I964 to I987, became the first international organization to impose, albeit hypocritically, international economic sanctions against the nationalist political leaders with their families, framed by Western countries.

- The century's UN political framework in the political context of Africa was their illegal joint military attack operation against an independent and sovereign UN member state and its president Gbagbo of Cote d'Ivoire in the post-election crisis of $20 \mathrm{OI}$ with the French neo-colonial army. The UN-led French army used force against a sovereign state and forcibly seized and imprisoned a member and his relatives. He was sent to the International Court of Justice which some super-states had refused to allow their former presidents to be tried for war crimes worldwide.

- In Libya Jamahiriya, the UN was used by the super-states to frame Muammar Gaddafi. Resolution I973 of the UNSC, adopted on I7 March 20II, approved all necessary measures to protect Libyan civilians but did not include the protection of a sitting president. The report on the Libyan crisis blamed the rebels, government forces and UN military coalitions headed by the NATO for unlawful shootings, violations of human rights, rape and senseless bombing, but they were not put before the courts. NATO's participation in the war and violation of UN resolutions in Libya was part of UN erratic behaviour.

From the foregoing, it is adequate to state that the super-states acting on behalf of the UN in Africa have little to do with the stability, security, economic growth and good governance, which are UN cardinal objectives (Ulfstein and Christiansen 20I3). In Côte d'Ivoire and Libya, the situation of France and NATO-led interventions exemplifies the context above (Wyss 2003; Glanville 2013; Dembinski and Reinold 20II; Bellamy and Williams 20II). Instead of promoting democracy and good governance, the UN acting through the super-states has been planting stooges in various African states.

African states and their leaders are neither respected nor recognized as critical factors in the international system. The modicum of their acceptance depends on their submissiveness to the super-states. The super-states identify African states based on the behaviours of the leaders. We classified their behaviours into three - the "good boy," the "bad boy" and the "good boy 
turned radical." The super-states assigned to Côte d'Ivoire and Libya classifications of the "good boy turned radical" and the "bad boy" based on their leaders' struggle for statehood/regime survival. Thus, such label reinforced the crises in Côte d'Ivoire and Libya.

\section{The UN, the super-states and the Framing of the Ivorian Crisis}

The state means everything to the African political class. They were planted in the various African states by imperialism and colonialism, not to represent the people but outside interests and engaged in primitive accumulation on the other. Hence, Africa's representation is full of subjectivity from its strong partners, and that was the reflection in the Ivorian crisis. The Ivorian crisis is frequently described in a simplistic way as a cultural conflict between the Muslim North and Christian South, between the savannah ethnic groups and those in the forest region. This reductionist approach, (the western countries) and the media rely squarely on what Bovcon (2009, 2-3) described as the "primordial assumption that understands ethnicity as an objectively given innate and immediate substance of human identity, which can lead to confrontation when confronted with a different cultural conception."

Further elaborating, Bovcon $(2009,2)$ clarified that in Côte d'Ivoire, the Ivorian crisis was rooted in a multi-layered conflict of race, autochthony and citizenship to discriminate economically, politically and socially against others. Without explaining its full meaning, President Henri Bedie introduced the concept of "Ivorite," making it available to most xenophobic interpretations to perpetuate social, economic and political exclusion on Côte d'Ivoire. In this context, Bovcon preferred to address factors that influenced the Ivorian crisis separately, here we chose to investigate it holistically in the sense of a power struggle in Côte d'Ivoire where the French colonial masters, as they were named, had ignored democracy and made the late President Boigny a life president, equal to the Ivorian state and seen as nobody is capable of becoming president.

The argument is that there had been no strong political-institutional framework to fill the power vacuum before the death of Boigny. The one-party rule more or less led Boigny to transform himself into a sort of institution. The lack of institutional mechanisms to control the transfer of power provided the opportunity for the political elites to dangerously politicize identity, lead- 
ing to the Cote d'Ivoire crisis. With Boigny's health deterioration and death in December 1993, Bédié, the president of the National Assembly took over the presidency immediately and introduced the Ivorite identity was mainly to edge out President Alassane Dramane Ouattara, who has been overseeing the affairs of governance in the country before Boigny's death. It was also aimed at displacing other opposition political leaders who missed out in the post-Boigny death power struggle. The Ivorian concept of power struggle produced a problem of nationality which divided the country.

Unfortunately, the concept of citizenship used for the ethnic exclusion of the Northern political class has benefited southern Côte d'Ivoire. Beneficiaries of identity politics focused on citizenship status were the then-President Bedie, General Robert Gue, Laurent Gbagbo and President Ouattara. The UN was more interested in the outcome of the election, without going beyond the election to look at the power struggle tools divide and rule that was used during electioneering. Suffice we state that the divide and rule politics in Côte d'Ivoire was learnt from the former colonial powers. The action that led to Gbagbo's arrest and a breach of Côte d'Ivoire's sovereignty was to serve the interest of the French, not the UN or the Ivorian people. The people's concern in Côte d'Ivoire can only be addressed by institutional change. In Côte d'Ivoire, it is the constitutional court that, although the UN-supported electoral commission and based on that criminalized Gbagbo, a sitting president, without looking at the issue of citizenship that caused the crisis, allowed the constitutional court, not the electoral body to declare the final result. This situation was at the root of the Ivorian civil war.

\section{The UN, the super-states and the geopolitics of the Libyan crisis}

Under Colonel Muammar Gaddafi, Libya was known as one of the revolutionary states that transformed into a good boy dictator but not without blemishes in the super-states' view. The Arab Spring offered the chance for Libya and Muammar Gaddafi's regime stepped into a condition that it was already catching up with fever. In the name of nationalism, self-determination, and popular sovereignty, Gaddafi led a revolution against the Libyan monarchy. Ruling for more than four decades, people were detested by the 
Gaddafi rule. The opposition groups, using the Arab Spring ${ }^{10}$ as a means to end Gaddafi's regime in the name of popular sovereignty, argued that the regime had been entrenched for more than four decades using all types of tools to maintain itself in place. The opposition-led popular war in Libya, sponsored by the UN-NATO alliance against Gaddafi's regime, was brutal (Lyall-Grant and Dormandy 20II; Wedgwood and Dorn 20I5). There was the abused of popular sovereignty and the protection of civilians provided by the UNSC mandate was not exclusively kept by the coalition to prevent the destruction of life and property in Libya (Plett 20II).

Unfortunately, the revolution in Libya degenerated into a civil war, which Western countries call “armed uprising." The UN's involvement in the armed rebellion in Libya remains a concern of this report. Agreed that the government of Libya was blamed for unlawful use of force against civilians and opposition forces, who were the opponents? While the Arab Springs in Egypt and Tunisia were all civil affairs organized by civil society organizations, it was conducted in Libya by large-scale, externally supported armed groups. The enforcement of the use of force was necessary to Gaddafi for the protection and survival of the state and regime. In the process, Gaddafi was brutally assassinated by the rebel forces supported by the super-states operating on behalf of the UN.

In other North African countries where the Arab spring has occurred, the uprising against Gaddafi and the regime in Libya has the same background. Not only did the Arab spring happen in a day, but it has also been a phenomenon incubated among the Arab population for decades. Some of the factors that inspired the Arab Spring were limited civil liberties, inequality, growing wealth disparities, lack of dignity, impunity for the police and fraudulent elections (Africa Centre for Strategic Studies 20II, 7-8). While UN Resolutions 1973 and 1970 "excluded any sort of foreign invasion on any part of Libya”, it called for an immediate ceasefire, dialogue and the use of all appropriate measures to safeguard Libyan civilians by protecting airspace and effective compliance measures for the arms embargo on Libya. The US and NATO, which later assumed charge of the coalition operations in Libya to implement the I973 UNSC Resolution, were seen as working on behalf of the UN, but their actions in Libya were to oust Gaddafi from power (Erdağ 20I7).

Io This is a series of anti-government uprisings, protests and demonstrations in countries across the Gulf and North Africa that took place in early 20I0. The Arab Spring began as a reaction to the regime's suppression and poor living conditions in Tunisia (Noueihed 20II; Gowan 2013). It has led to the downfall of several governments, including Libya's Gaddafi. In the popular uprising, the UNSC was split into super-state Western (US and NATO allies) and super-state Eastern (Russia and China). 
President Barack Obama's appeal that Gaddafi should give up power was not expressed in the UNSC Resolution I973. The U.S. coalition forces neutralized Libya's Air Defence Systems, Air Forces, and pro-Gaddafi ground forces and tacitly supported the opposition forces that later turned into the Transitions National Council (TNC) after killing Gaddafi, what supported our arguments that it represented super-state interests in the UN (Ulfstein and Christiansen 2013).

While other analysts concerned with the Libyan crisis evaluate from Gaddafi's point of view, our analysis is from Libya's perspective. There are many Gaddafi-like leaders in charge of state power around the world, which the UN and the Western powers have warmly engaged and provided immunity, despite overstaying in power for decades. These leaders are retained so long as they continue to defend and advance the interests of the superstates. The super-states under the UN cover have violated Libya's sovereignty (Glanville 20I3; Adebajo 20I6; Erdağ 20I7). The UN and the super-states, in defiance of the values of "sovereignty" as enshrined in UN General Assembly Resolution 2I3I (XX) adopted on 2I December I965, assisted the rebel groups to unseat President Gaddafi. The resolution stated that "the principle of the non-intervention of states in the internal and external affairs of other states is essential to the fulfilment of the purposes and principles of the United Nations" (Declaration on the Inadmissibility of Intervention in the Domestic Affairs of States and the Protection of their Independence and Sovereignty I966). The super-states helped rebellion against the legitimate government of Libya and sent a false signal for world peace and stability for which the UN stands.

In light of this, Islamist movements which helped the UN to fight the war in Libya in the most violent way have infested Africa and the world at large. Omotola (20I4), reflecting on the issue, noted with the increasing role of the Islamist forces after the Arab spring has generated serious concern for the West, not only about the assumed incompatibility of Islamist ideology with democratic values but also about the possibility of Islamist regimes pushing the "clash of civilizations" which is also responsible for the rise of local Islamist forces challenging the existing order in other parts of the world. The post-Gaddafi spill-over effects of Islamist jihadist movements have raised concerns in Mali, Nigeria and the CAR. Jihadist Islamic movements in those countries have become voracious and challenge the sovereignty of the state. For example, in Nigeria, the Boko Haram, which has survived for over a decade, challenges state sovereignty in Chad, Cameroon and Niger. Islamists in these countries have all benefited from arms used in the civil war in Libya, fuelled by various Islamist movements and funded by Western 
countries in terms of infrastructure and arms, which they now use to counter Western interests globally (Basar 20I2; Eaton 20I8).

\section{Conclusion and recommendations}

This study was set to interrogate the UN's erratic behaviour in Africa's global governance. We concluded from the study of the erratic behaviour of UN global governance in African states that the UN has played a reactionary role, not a proactive one. In this analysis, the cases of Côte d'Ivoire and Libya revealed that the UN was reactionary, as removing Gbagbo and Gaddafi from power did not mean ending the problems that led to the crises in those countries. The post-Gaddafi problems in Libya have proved difficult for super-states and the UN to address and are deteriorating, capable of leading to the collapse of the state. The UN's position in global governance in Africa has failed with the rise of jihadist Islamic movements and other insurgent groups in the post-Gaddafi period, and the spread through other regions in Africa. It seems that the situation in Côte d'Ivoire is calm but it does not mean that a permanent solution has been addressed to the bewildering problems of statehood.

The greatest barrier to understanding world peace and stability has not been the UN but the super-states, which sheltered under UN resolutions and mandates to work in their interests to promote collective imperialism. It is either Western models are followed by a stooge or the behaviour of the state and its political leaders are interpreted as being recalcitrant using UN resolution to justify actions against them, executed by the super-states on behalf of the UN in violation of their sovereignty. As part of the UN mandate to achieve global governance, these super-states do not care about peace, security, poverty reduction, weak democratic institutions or good governance. Global governance story remains an unfinished journey, as we struggle to find its satisfying end.

Global governance is what the French would call faute de Deux, a kind of replacement or surrogate to the contemporary world for authority and enforcement. The argument is that Western political and military forces have eroded the UN's international legitimacy in global governance, particularly in Africa and elsewhere in the global south. Since its formation, after World War II to assert its international role in global governance, the UN has become ineffective and deeply reactionary to broker international peace and harmony among its member states. The UN mandate to the super-states to intervene 
in the conflicts occurring in the countries in the global south, particularly in Africa, amounts to a violation of state sovereignty. The method of representing the current international politics of the 2Ist century made up of many philosophies and complex social dynamics especially in the global south or Africa needs to be fully overhauled. We must state that Western philosophies or models cannot be forced on African citizens, given the socio-economic and political structure and conditions of the continent that vary strikingly from the Western countries in nature and meaning.

Global governance needs to reinforce respect for life, liberty, justice, equity, mutual respect and care, and dignity no matter how different a country's political system is from another. Global governance embraces new social principles, including the concepts of autonomy and self-determination that cannot be followed without recognizing their effect on other members of the global community. Consequently, the UN should refrain from the use of super-states to help to resolve challenges in the global south, especially Africa by promoting internal institutional frameworks on the continent. In many circumstances, the super-states have taken advantage of the UN to pursue their interests, which are beyond the national reach of any country in Africa. Given that global governance is not restricted to the UN alone, regional and sub-regional organizations in Africa have the potential and should be supported to resolve internal conflicts through functions of democratic support and the promotion of conditions that entrench democratic governance, support stability and popular sovereignty.

\section{References}

Adebajo, Adekeye. 20I6. "The Revolt Against the West: Intervention and Sovereignty". Third World Quarterly 37 (7): II87-I202.

Amin, Samir. 2003. "Geostrategy of Contemporary Imperialism and the Middle East and the Middle East". Kasarinlan: Philippine Journal of Third World Studies I8 (I-2): 5-4I.

. 2004. "Geopolitics of Contemporary Imperialism". Latin American Council of Social Sciences (CLACSO), http://bibliotecavirtual.clacso. org.ar/clacso/se/20100613064644/5Amin.pdf.

. 2015. "Contemporary Imperialism". Monthly Review 67 (3), (July-August), https://monthlyreview.org/2015/07/oI/contemporary-imperialism/. 
Basar, Eray. 20I2. "Report Update: Unsecured Libyan Weapons - Regional Impactand Possible Threats". Civil-Military Fusion Centre. November. https://reliefweb.int/sites/reliefweb.int/files/resources/20I2IO3I \%20Libya\%2oWeapons\%2oUpdate_final.pdf.

Bellamy, Alex J. and Williams, Paul D. 20II. "The New Politics of Protection? Côte d'Ivoire, Libya and the Responsibility to Protect". International Affairs 87 (4): 825-850.

Boulden, Jane. 2013. "The United Nations Security Council and Conflict in Africa". In Responding to Conflict in Africa: The United Nations and Regional Organizations, edited by Jane Boulden, 13-32. United States: Palgrave Macmillan.

Bovcon, Maja. 2009. “France's Conflict Resolution Strategy in Côte d'Ivoire and its Ethical Implications". African Studies Quarterly II(I): I-24. http://www.africa.ufl.edu/asq/vir/viriıaı.pdf.

Cassese, Antonio. I986. International Law in a Divided World. Oxford: Clarendon Press.

. I991. "Violence, War and the Rule of Law in the International Community". In Political Theory Today, edited by David M. Held. Cambridge: Cambridge Polity Press.

Chafer, Tony. F. 2002. "African Relations: No Longer so Exceptional?” African Affairs, Regional African Society IOI (402): 343-363, January.

Chamberlain, Muriel E. 2013. The Scramble for Africa. New York, NY: Routledge.

Declaration on the Inadmissibility of Intervention in the Domestic Affairs of States and the Protection of their Independence and Sovereignty. I966. The American Journal of International Law, 60 (3): 662.

Dembinski, Matthias and Reinold, Theresa. 20II. "Libya and the Future of the Responsibility to Protect - African and European Perspectives". PRIF-Report No. I07: I-30. Peace Research Institute Frankfurt (PRIF), Frankfurt am Main, Germany.

Eaton, Tim. 20I8. "Libya's War Economy Predation, Profiteering and State Weakness". The Middle East and North Africa Programme, Chatam House, April. https://www.chathamhouse.org/sites/default/files/ publications/research/20I8-04-I2-libyas-war-economy-eaton-final. pdf.

Erdağ, Ramazan. 20I7. Libya in the Arab Spring: From Revolution to Insecurity. New York: Palgrave Macmillan. 
Frank, Andre Gunder. I978. Dependent Accumulation and Underdevelopment. London and Basingstoke: The Macmillan Press Ltd.

Gálvez, Eduardo. 20I4. "Multilateralism, the United Nations and Global Governance. Background paper for the seminar 'The United Nations in Global Governance'" ECLAC, Santiago, 8-9, August. https://www.un.org/esa/ffd/wp-content/uploads/2014/ı/66geg_ ECLACseminar_EGalvez.pdf.

Gathara, Patrick. 20I9. "Berlin I884: Remembering the Conference that Divided Africa". Al-Jazeera, I5 November. https://www.aljazeera.com/ indepth/opinion/berlin-I884-remembering-conference-divided-africa-I9III5II0808625.html.

Glanville, Luke. 2013. "Intervention in Libya: From Sovereign Consent to Regional Consent”. International Studies Perspectives I4(3): 325-342.

Global Change Forum. (n.d). Global risk. https://globalchallenges.org/global-risks /

Gordenker, Leon and Weiss, Thomas G. I995. "Global Governance: AnDeclaration on the Inadmissibility of Intervention in the Domestic Affairs of States and the Protection of their Independence and Sovereignty Analytical Approaches and Dimensions", Third World Quarterly i6(3): 357-387.

Goulding, Marrack. I999. "The United Nations and Conflict in Africa since the Cold War". African Affairs 98(391): I55-166.

Gowan, Richard. 20I3. Arab Awakening. New York: Centre on International Cooperation (CIC), New York University. https://cic.nyu.edu/topic/ arab-awakening.

Heath, Elizabeth. 2010. "Berlin Conference of I884-I885." In Encyclopaedia of Africa, edited by Henry Louis Gates Jr. and Kwame Anthony Appiah. Oxford: Oxford University Press.

Jackson, Robert H. I990. Quasi-States Sovereignty: International Relations and the Third World. Cambridge: Cambridge University Press.

Johnson, D. I975. "Book reviews : The West and the Rest of Us: White Predators, Black Slavers and the African Exile by CHINWEIZU (New York, Random House, I975). 520 pp. \$15.00 Cloth. \$4.95 Paper". Race \& Class I7(I): 107-108.

Lyall-Grant, A. Mark and Dormandy, Xenia. 20II. "Is there an Arab Summer? The UN's Response to the Arab Spring”. 27 June. Chatham House. https://www.chathamhouse.org/sites/default/files/2706IIlyall_ grant.pdf. 
Murthy, C. S. R. 20I8. "United Nations and the Arab Spring: Role in Libya, Syria, and Yemen". Contemporary Review of the Middle East 5(2): II6I36.

Noueihed, Lin. 20II. "Peddler's Martyrdom launched Tunisia's Revolution". 20 January. Reuters World News. https://uk.reuters.com/article/ uk-tunisia-protests-bouazizi/peddlers-martyrdom-launched-tunisias-revolution-idUKTRE7oI7TV2oIIoII9.

Omotola, J. Shola. 20I4. "Post-Arab Spring: ECOWAS and the Promotion of Democratic Values in West Africa”. West Africa Insight, March, 9-II.

Overseas Development Institute (ODI). I999. Briefing Paper I999, July.

Palmer, Norman D. and Perkins, Howard C. 2004. International Relation: The World Community in Transition India. India: AITBS Publishers.

Plett, Barbara. 20II. "UN Security Council Middle Powers' Arab Spring Dilemma". British Broadcasting Corporation. 8 November. https:// www.bbc.com/news/world-middle-east-I5628006.

Sartre, Jean-Paul. 200I. Colonialism and Neo-Colonialism. Paris: Rutledge.

Segell, Glen. 20I9. "Neo-colonialism in Africa and the Cases of Turkey and Iran". Insight on Africa II(2): I84-199.

Shively, W. Phillips. 2008. Power and Choice: Introduction to Political Science. Boston: McGraw-Hill.

The Africa Center for Strategic Studies. 20Iı. "Africa and the Arab Spring: A New Era of Democratic Expectations.” ACSS Special Report No. I, November. Africa Centre for Strategic Studies, Washington, D.C.

Ulfstein, Geir and Christiansen, Hege F. 2013. "The Legality of the NATO Bombing in Libya". The International and Comparative Law Quarterly 62(I): I59-I7I.

United Nations. 2000. "The United Nations system working together for a Better Nigeria", United Nations Information Centre Lagos.

. 2010. Operational Concept on the Protection of Civilians. New York: Department for Peacekeeping Operations and Department for Field Support.

. 20I4. "Global governance and global rules for development in the post-20I5 era". Committee for Development Policy, Economic and Social Affairs, United Nations. https://www.un.org/en/development/desa/policy/cdp/cdp_publications/20I4cdppolicynote.pdf. 
. 20I5. The Protection of Civilians in United Nations Peacekeeping. New Nork: DPKO and DFS Policy.

United Nations General Assembly. I965. "I965 Declaration on Independence and Sovereignty", (2Ist December I965).

United Nations Intellectual History Project. 2009. “The UN's Role in Global Governance," Briefing Note no. I5, August, UN Intellectual History Project, www.unhistory.org/briefing/I5GlobalGov.pdf.

Wedgwood, Andrew and Dorn, A. Walter. 2015. “NATO's Libya Campaign 20II: Just or Unjust to What Degree?” Diplomacy \& Statecraft 26(2): 34I-362.

Weiss, Thomas G. and Gordenker, Leon (ed). I996. NGOs, the UN, and Global Governance. Boulder: Lynne Rienner.

Weiss, Thomas G., Carayannis, Tatiana and Jolly, Richard. 2009. "The "Third" United Nations". Global Governance I5(I): I23-I42. https:// www.jstor.org/stable/27800742.

Wyss, Marco. 2013. “The Gendarme Stays in Africa: France's Military Role in Côte d'Ivoire". African Conflict and Peacebuilding Review 3(I): 8IIII.

Yachyshen, Dylan. 2020. "Great Power Competition and the Scramble for Africa. National Security Programme", Foreign Policy Research Institute, Philadelphia. https://www.fpri.org/article/2020/04/ great-power-competition-and-the-scramble-for-africa/.

Young, C. I99I. "The Heritage of Colonialism," In Africa in World Politics, edited by John W. Harbeson and Donald Rothchild. Oxford: West View Press.

\section{ABSTRACT}

This study questions the erratic behaviour of the UN and Africa's global governance to understand how the State has become a smokescreen for global security. Using the African case of Cote d'Ivoire and Libya, the study argues that the UN's role in global governance has been rather reactionary to the challenges posed by the political leadership in Africa without considering the aftermath. Using super-States to execute global governance on their behalf in the global south, the UN's behaviour has erratically undermined the sovereignty of weaker states. It also continues the geopolitical struggles at the level of the United Nations Security Council between super-States - the United States, United Kingdom and France versus China and Russia -, producing all sorts of undesirable outcomes that shape the process and the execution of the current approach of UN interventions in conflict around the world. The study suggests that the UN and international powers should encourage 
the strengthening and utilization of internal institutional mechanisms guided by appropriate UN institutions away from military actions to solve problems faced by states and not to use the UN to achieve interests outside the national scope of the weaker states.

\section{KEYWORDS}

Côte d'Ivoire; Erratic behaviour; Global governance; Libya; The UN; The super-states.

Received on April 28, 2020

Accepted on July 28, 2020 